\title{
ANALISIS POTENSI EROSI PADA PENGGUNAAN LAHAN DAERAH ALIRAN SUNGAI SEDAU DI KECAMATAN SINGKAWANG SELATAN
}

\author{
Janixon Sinaga ${ }^{1}$, Kartini $^{2}$, Erni Yuniarti ${ }^{1}$ \\ ${ }^{1}$ Program Studi Teknik Lingkungan, Fakultas Teknik, Universitas Tanjungpura, Pontianak \\ ${ }^{2}$ Program Studi Teknik Sipil, Jurusan Teknik Sipil, Fakultas Teknik, Universitas Tanjungpura, Pontianak \\ Email: 17.pande@gmail.com
}

\begin{abstract}
ABSTRAK
Penelitian ini bertujuanuntuk menganalisa tingkat potensi erosi akibat perubahan tata guna lahan yang terjadi di daerah aliran Sungai Sedau Kecamatan Singkawang Selatan dan mengetahui pengaruh terjadinya erosi terhadap kualitas air Sungai Sedau serta memberikan rekomendasi upaya konservasi lahan potensial erosi. Metode analisis potensi erosi menggunakan metode USLE berbasis Sistem Informasi Geografis (ArcMap) dan untuk menganalisis kualitas air digunakan metode grab sampling (sampel sesaat) dan pemeriksaan di laboratorium dengan parameter yang diukur yakni Kekeruhan dan TSS. Hasil analisa perhitungan menunjukkan, laju potensi erosi di DAS Sedau dalam jumlah yang besar terjadi pada tahun 2010 dengan nilai erosivitas hujan sebesar 3489,94 ton.m/ha/cm hujan, mengakibatkanluas lahan yang masuk dalam kriteria kelas bahaya erosi berat dan sangat berat sebesar 4303,09 ha. Laju potensi erosi di DAS Sedau dalam jumlah yang kecil terjadi pada tahun 2011 dengan nilai erosivitas hujan hanya sebesar 535,71 ton.m/ha/cm hujan mengakibatkan luas lahan yang masuk dalam kriteria kelas bahaya erosi berat dan sangat berat hanya sebesar 271,95 ha. Untuk hasil pemeriksaan kualitas air, diketahui parameter kekeruhan pada dua sampel air uji melebihi standar baku mutu air bersih menurut Peraturan Menteri Kesehatan RI Nomor : 416/MENKES/PER/IX/1990,yang mana kandungan kekeruhan pada dua sampel air uji yakni T1 =26,6 mg/l dan T2=25,1 $\mathrm{mg} / \mathrm{l}$. Berdasarkan hasil identifikasi lahan potensial erosi diketahui bahwa pertanian lahan kering, permukiman dan kawasan wisata merupakan penyumbang terbesar potensi erosi. Adapun rekomendasi upaya konservasi lahan yang dapat dilakukan pada lahan potensial erosi tersebut yakni dengan melakukan tidakan konservasi tanah secara vegetative dan mekanik.
\end{abstract}

Kata kunci : Erosi di DAS Sedau, USLE, Sistem Informasi Geografis, Upaya Konservasi

\section{ABSTRACT}

This study aims to analyze the level of potential erosion due to land use changes that occur in the Sedau Watershed District of South Singkawang and determine the effect of erosion on Sedau river water quality and makes recommendations on potential land erosion conservation. Methods of analysis of potential erosion using USLE method based Geographic Information System (ArcMap) and used to analyze the water quality grab sampling method (instantaneous sample) and examination in the laboratory with the measured parameter is a TSS and Turbidity. The result of the calculation analysis showed, potential rate of erosion in SedauWatershed occurs in large numbers in 2010 with rain erosivitas value of 3489,94 ton. $\mathrm{m} / \mathrm{ha} / \mathrm{cm}$ rain, resulting in land area qualifies as severe erosion hazard class and very heavy at 4303,09 ha. Potential rate of erosion in Sedau Watershed occurs in small quantities in 2011 with just the rain erosivitas value of 535,71 ton. $\mathrm{m} / \mathrm{ha} / \mathrm{cm}$ rain, resulting in land area qualifies erosion hazard class and the very heavy weight of only 271,95 ha. For the results of water quality, are known turbidy parameters in the two water test samples exceeds water quality standards according to Regulation of the Minister of Health Decree No. 416 / Menkes / PER / IX / 1990, which turbidity content of the two water tes samples is $T 1=26,6 \mathrm{mg} / \mathrm{l}$ dan $T 2=25,1 \mathrm{mg} / \mathrm{l}$. Based on identification of erosion potential land known that the agricultural land, residential and tourist area is known that the agricultural land, residential and tourist area is the largest contributor to the erosion potential. As for land conservation recommendations can be made on the erosion potential by soil conservation measures vegetative and mechanics.

Keywords : Erosion in Sedau Watershed, USLE, Geographic Information Systems, Conservation Measures

\section{Latar Belakang}

Perubahan tata guna lahan pada daerah aliran sungai (DAS) seringkali terjadi yang mana akan menimbulkan berbagai macam permasalahan. Singkawang Selatan khususnya DAS Sedau merupakan salah satu kawasan yang terdapat banyak perubahan tata guna lahan yang mana dapat dilihat pada peta tata guna lahan tahun 2003 dan 2010 (BAPPEDA, 2012).Salah satu perubahan tata guna lahan yang dapat dilihat 
dari kedua peta tersebut yakni diketahui banyaknya daerah kawasan hutan alam yang telah berkurang akibat pertumbuhan penduduk dan daerah pertanian yang meningkat setiap tahunnya. Hal inilah yang dapat mengakibatkan banyaknya tutupan lahan yang kurang baik untuk meminimalisir terjadinya erosi yang berdampak dengan terjadinya sedimentasi di aliran Sungai Sedau sehingga menyebabkan menurunnya fungsi sungai untuk menampung aliran air yang akhirnya menimbulkan genangan/banjir.Banjir dan genangan yang terjadi serta perubahan tata guna lahan menyebabkan kawasan ini layak untuk dijadikan kawasan konservasi. Berdasarkan permasalahan tersebut itulah, maka penulis berencana melakukan analisa tingkat potensi erosi akibat perubahan tata guna lahan di daerah aliran Sungai Sedau Kecamatan Singkawang Selatan, yang mana hasil dari analisa tersebut bisa memberikan gambaran spasial tingkat erosi tanah yang lebih spesifik dari nilai pixel-pixel yang ada yang dapat berguna dalam penentuan arahan penggunaan lahan yang lebih sesuai dengan peruntukannya.

\section{Tinjauan Pustaka}

A. Erosi

Erosi adalah suatu proses atau peristiwa hilangnya lapisan permukaan tanah atas, baik disebabkan oleh pergerakan air maupun angin (Suripin, 2004). Erosi merupakan tiga proses yang berurutan, yaitu pelepasan (detachment), pengangkutan (transportation), dan pengendapan (deposition) bahan-bahan tanah oleh penyebab erosi (Asdak, 1995).

Percikan air hujan merupakan media utama pelepasan partikel tanah pada erosi yang disebabkan oleh air.Pada saat butiran air hujan mengenai permukaan tanah yang gundul, partikel tanah terlepas dan terlempar ke udara.Karena gravitasi bumi, partikel tersebut jatuh kembali ke bumi.Pada lahan miring partikel-partikel tanah tersebar ke arah bawah searah lereng. Partikel-partikel tanah yang terlepas akan menyumbat pori-pori tanah. Percikan air hujan juga menimbulkan pembentukan lapisan tanah keras pada lapisan permukaan. Hal ini mengakibatkan menurunnya kapasitas dan laju infiltrasi tanah. Pada kondisi dimana intensitas hujan melebihi laju infiltrasi, maka akan terjadi genangan air di permukaan tanah, yang kemudian akan menjadi aliran permukaan. Aliran permukaan ini menyediakan energi untuk mengangkut partikel-pertikel yang terlepas baik oleh percikan air hujan maupun oleh adanya aliran permukaan itu sendiri. Pada saat energi aliran permukaan menurun dan tidak mampu lagi mengangkut partikel tanah yang terlepas, maka partikel tanah tersebut akan mengendap baik untuk sementara atau tetap (Suripin, 2004).

\section{B. Erosi yang diijinkan.}

Erosi tidak bisa dihilangkan sama sekali atau tingkat erosinya nol, khususnya untuk lahan-lahan pertanian. Tindakan yang dilakukan adalah dengan mengusahakan supaya erosi yang terjadi masih dibawah ambang batas yang maksimum (soil loss tolerance), yaitu besarnya erosi yang tidak melebihi laju pembentukan tanah (Suripin, 2004). Untuk memberikan gambaran tentang potensi erosi yang hasilkan, United States Department of Agriculture (USDA) telah menetapkan klasifikasi bahaya erosi berdasarkan laju erosi yang dihasilkan dalam ton/ha/tahun seperti diperlihatkan pada Tabel 1 (Kironoto, 2003).Klasifikasi bahaya erosi ini dapat memberikan gambaran, apakah tingkat erosi yang terjadi pada suatu lahan ataupun DAS sudah termasuk dalam tingkatan yang membahayakan atau tidak, sehingga dapat dijadikan pedoman didalam pengelolaan DAS.

Tabel 1. Klasifikasi Bahaya Erosi

\begin{tabular}{ccc}
\hline Kelas Bahaya Erosi & Laju erosi, Ea (ton/ha/tahun) & Keterangan \\
\hline I & $<15$ & sangat ringan \\
II & $15-60$ & ringan \\
III & $60-180$ & sedang \\
IV & $180-480$ & berat \\
V & $>480$ & sangat berat \\
\hline
\end{tabular}

\section{Model Prediksi Erosi (USLE)}

Salah satu model untuk memprediksi laju erosi pada permukaan lahan adalah USLE (Universal Soil Loss Equation) yang dikembangkan oleh Wischmeier dan Smith tahun 1985 (dalam Sutapa, 2010), dimana metode USLE dapat dimanfaatkan untuk memprakirakan besarnya erosi untuk berbagai macam kondisi tataguna lahan dan kondisi iklim yang berbeda.USLE memungkinkan perencana memprediksi 
laju erosi rata-rata lahan tertentu pada suatu kemiringan dengan pola hujan tertentu untuk setiap jenis tanah dan penerapan pengelolaan lahan (tindakan konservasi lahan).USLE dirancang untuk memprediksi erosi jangka panjang dari erosi lembar (sheet erosion) dan erosi alur di bawah kondisi tertentu.Persamaan tersebut juga dapat memprediksi erosi pada lahan-lahan non pertanian, tapi tidak dapat untuk memprediksi pengendapan dan tidak memperhitungkan hasil sedimen dari erosi parit, tebing sungai dan dasar sungai (Suripin, 2004). Secara matematis model USLE dinyatakan dengan :

$E_{a}=R \times K \times L S \times C \times P$

Dimana : $E_{\mathrm{a}}=$ banyaknya tanah yang hilang (ton/ha/tahun)

$\mathrm{R}$ = Faktor erosivitas hujan

$\mathrm{K}=$ Faktor erodibiltas tanah

LS = Faktor panjang dan kemiringan lereng

$C$ = Faktor penutup lahan

$\mathrm{P}=$ Faktor tindakan konservasi

\section{Parameter Kualitas Air}

\section{* Kekeruhan}

Kekeruhan menggambarkan sifat optik air yang ditentukan berdasarkan banyaknya cahaya yang diserap dan dipancarkan oleh bahan-bahan yang terdapat didalam air.Kekeruhan dapat disebabkan oleh tanah liat, lumpur, bahan-bahan organik yang berasal dari erosi tanah, industri serta pembuangan limbah maupun sampah yang berbentuk partikel-partikel kecil yang tersuspensi. Kadar kekeruhan maksimum yang diperbolehkan untuk kualitas air bersih dapat dilihat pada PERMENKES Republik Indonesia Nomor : 416/MENKES/PER/IX/1990.

\section{* TSS (Total Suspended Solid)}

Total suspended solid atau padatan tersuspensi total (TSS) adalah residu dari padatan total yang tertahan oleh saringan dengan ukuran partikel maksimal $2 \mu \mathrm{m}$ atau lebih besar dari ukuran partikel koloid. TSS menyebabkan kekeruhan pada air akibat padatan tidak terlarut dan tidak dapat langsung mengendap.TSS terdiri dari partikel-partikel yang ukuran maupun beratnya lebih kecil dari sedimen, misalnya tanah liat, bahan-bahan organik tertentu, sel-sel mikroorganisme, dan sebagainya (Nasution, 2008). Ambang batas kadarTSS yang diperbolehkan untuk kualitas air bersih dapat dilihat dalam PP Republik Indonesia Nomor 82 Tahun 2001

\section{Metodologi Penelitian}

\section{A. Lokasi Penelitian}

Penelitian ini dilakukan untuk menganalisis tingkat potensi erosi pada Daerah Aliran Sungai (DAS) Sedau, Kelurahan Sedau, Kecamatan Singkawang Selatan.

\section{B. Metode Analisis Data}

Metode analisis data dilakukan dengan penyusunan model data spasial menggunakan pendekatan Sistim Informasi Geografis (SIG) dalam hal ini menggunakan perangkat lunak ArcMap GIS. Keempat jenis peta yang digunakan dalam analisis ini, di dalam ArcMap dinyatakan sebagai layer-layer dalam bentuk shape file (shp) dan dibuat dengan skala yang sama. ArcMap dapat melakukan input secara interaktif, proses editing yang sangat fleksibel dan output sesuai kebutuhan. Setiap layer yang mewakili setiap peta selalu dilengkapi dengan data digital yang dapat diolah dan diakses pada perangkat pengolah data yang lain seperti Microsoft Exell. Hasil akhir dari analisis SIG ini adalah unitunit lahan dengan segala data atribut yang dihasilkan dari proses tumpang tindih layer.

Secara lebih rinci pengolahan data dilakukan dengan sebagai berikut :

- Peta rupa bumi skala 1 : 50.000 diperlukan untuk mengetahui batas-batas setiap DAS dan dihitung luasnya dengan menggunakan ArcMap.

- Data curah hujan diperlukan untuk menghitung nilai erosivitas hujan (R). Erosivitas hujan (R).

- Peta vegetasi berupa tata guna lahan digunakan untuk mendapatkan nilai "CP" pada daerah tersebut.

- Peta jenis tanah digunakan untuk mendapatkan faktor erodibilitas (K).

- Peta kemiringan lereng digunakan untuk menentukan nilai "LS". 
Setelah rincian pengolahan data diatas selesai dilakukan, maka selanjutnya dapat dilakukan kalkulasi peta dengan melakukan tumpang tindih/overlay terhadap peta-peta tersebut, kemudian setelah itu dapat dilakukan analisis erosi lahan dengan menggunakan metode USLE yakni dengan mengalikan semua faktor parameter USLE. Hasil dari analisis erosi tersebut dapat menghasilkan gambar/peta kelas bahaya erosi berdasarkan unit-unit lahan dari proses tumpang tindih/overlay terhadap peta-peta yang telah dijelaskan sebelumnya.

4. Hasil dan Pembahasan

A. Pengolahan Model Data Spasial

Pengolahan model data spasial dalam SIG ini yakni melakukan proses tumpang tindih layer/overlay (union) terhadap masing-masing layer yang mewakili setiap jenis peta, sehngga hasil yang akan didapatkan dari proses tumpang tindih layer ini ialah berupa unit-unit lahan beserta atribut data yang berisi jenis penggunaan lahan, jenis tanah dan kemiringan lereng pada masing-masing unit lahan tesebut. Pada penyusunan tugas akhir ini, dilakukan 2 kali proses tumpang tindih layer yakni :

1. Proses pertama : peta tata guna lahan DAS Sedau tahun 2003, peta jenis tanah DAS Sedau dan peta kemiringan lereng DAS Sedau dihasilkan 145 unit potongan DAS.

2. Proses kedua : peta tata guna lahan DAS Sedau tahun 2010, peta jenis tanah DAS Sedau dan peta kemiringan lereng DAS Sedau dihasilkan 140 unit potongan DAS.

\section{B. Menentukan Faktor Erosivitas Hujan $(R)$}

Persamaan USLE menetapkan bahwa nilai $R$ yang merupakan daya perusak hujan (erosivitas hujan) tahunan. Erosivitas hujan merupakan perkalian antara energi hujan total $(E)$ dan intensitas hujan maksimum 30 menit $\left(I_{30}\right)$. Kedua faktor tersebut, $E$ dan $I_{30}$ selanjutnya dapat ditulis sebagai $E I_{30}$. Bolls (1978 dalam Arsyad, 1989) mengembangkan persamaan penduga $\mathrm{El}_{30}$ sebagai berikut :

$\mathrm{El}_{30}=6,119$ (RAIN) $^{1,21}$ (DAYS) $^{-0,47}$ (MAXP) ${ }^{0,53}$

dimana :

RAIN = curah hujan rata-rata bulanan dalam sentimeter,

DAYS = jumlah hari hujan rata-rata per bulan,

MAXP= curah hujan maksimum selama 24 jam dalam bulan

bersangkutan.

Berikut merupakan hasil perhitungan erosivitas hujan di DAS Sedau Kecamatan Singkawang Selatan selama kurun waktu 10 tahun.

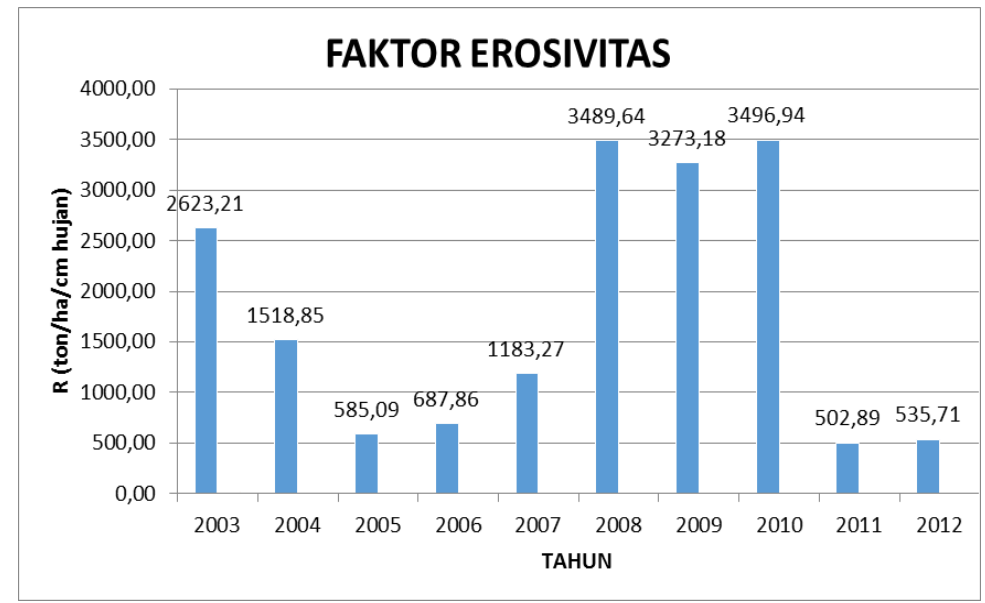

Gambar 1.Grafik faktor erosivitas hujan

Berdasarkan grafik diatas dapat dilihat bahwa indeks erosivitas hujan $(R)$ tertinggi terdapat pada tahun 2010 dengan jumlah 3496,94 ton.m/ha/cm hujan. Tingginya nilai $R$ disebabkan oleh curah hujan dan hari hujan yang tinggi, demikian juga dengan curah hujan maksimum selama 24 jam. Hal ini sesuai dengan pendapat Utomo (1989) yang menyatakan bahwa sifat hujan yang terpenting adalah curah hujan, intensitas dan distribusi. Ketiga sifat hujan ini secara bersama-sama akan menentukan kemampuan hujan untuk menghancurkan butir-butir tanah serta jumlah dan kecepatan limpasan. 


\section{Menentukan Faktor Erodibilitas Tanah (K)}

Penentuannilai erodibilitas tanah ialah kemampuan/ketahanan partikel tanah terhadap pengelupasan dan pemindahan tanah akibat energi kinetik hujan. Tabel 2 menunjukkan nilai faktor erodibilitas tanah berdasarkan jenis tanah di DAS Sedau. Nilai Faktor Erodibilitas tanah yang terdapat pada tabel 2 mengacu pada nilai erodibilitas tanah yang dikeluarkan oleh Dinas RLKT, Departemen Kehutanan dan juga hasil analisa laboratorium untuk menduga besarnya nilai erodibilitas tanah pada beberapa jenis tanah di Indonesia(Kironoto, 2003 dalam Sutapa, 2010).

Tabel 2. Nilai Faktor Erodibilitas Tanah di DAS Sedau

\begin{tabular}{llc}
\hline No & \multicolumn{1}{c}{ Jenis Tanah } & K \\
\hline 1 & Aluvial & 0,47 \\
2 & Latosol & 0,31 \\
3 & Podsolik & 0,16 \\
4 & Podsolik Merah Kuning & 0,32 \\
\hline
\end{tabular}

Hasil pada tabel 2 menunjukkan jenis tanah podsolik memiliki nilai faktor erodibilitas tanah (K) yang paling rendah, hal ini berarti unit lahan dengan jenis tanah podsolik memiliki kepekaan erosi yang lebih baik ketimbang jenis tanah lainnya yang terdapat dalam setiap unit lahan di DAS Sedau. Seperti yang dikemukakan oleh Arsyad, 1989 menyatakan bahwa sifat-sifat tanah yang mempengaruhi kepekaan erosi adalah sifat-sifat tanah yang mempengaruhi laju infiltrasi, permeabilitas dan kapasitas menahan air dan sifat-sifat tanah yang mempengaruhi ketahanan struktur tanah terhadap dispersi dan pengikisan oleh butir-butir hujan yang jatuh serta aliran permukaan.

\section{Menentukan Faktor Kemiringan Lereng (LS)}

Dalam praktek lapangan nilai $L$ sering dihitung sekaligus dengan faktor kecuraman (S) sebagai faktor kemiringan lereng (LS). Tabel 3 menunjukkan nilai faktor LS berdasarkan kemiringan lereng di DAS Sedau yang hasilnya mengacu pada nilai faktor kemiringan lerengberdasarkan kelas lerengyang dikeluarkan oleh Departemen Kehutanan (Sutapa, 2010).

Tabel 3.Nilai Faktor LS berdasarkan kemiringan lereng di DAS Sedau

\begin{tabular}{ccc}
\hline Kelas Lereng & Kemiringan Lereng (\%) & Nilai LS \\
\hline I & $0-8$ & 0,40 \\
II & $8-15$ & 1,40 \\
III & $15-25$ & 3,10 \\
IV & $25-40$ & 6,80 \\
V & $>40$ & 9,50 \\
\hline
\end{tabular}

Hasil pada tabel 3 menunjukkan bahwa kemiringan lereng yang besar pada suatu unit lahan akan berimbas pada nilai faktor LS yang besar, hal ini karena jika lereng permukaan tanah makin curam maka akan memperbesar kecepatan aliran permukaan yang dengan demikian memperbesar energi angkut air, selain itu dengan makin curamnya lereng, maka jumlah butir-butir tanah yang terpercik kebawah oleh tumbukan butir hujan semakin banyak dan lereng permukaan tanah menjadi dua kali lebih curam maka banyaknya erosi persatuan luas menjadi 2,0-2,5 kali lebih banyak.

\section{E. Menentukan Nilai Faktor Penggunaan Lahan dan Pengelolaan Tanah (CP)}

Nilai faktor CP ditentukan berdasarkan jenis penggunaan lahan dan pengelolaan lahan pada setiap unit lahan diDAS Sedau.Dalam penelitian ini data yang digunakan untuk menetukan nilai faktor penggunaan lahan dan pengelolaan tanah (CP) ialah peta tata guna lahan tahun 2003 dan 2010 di DAS Sedau. Nllai Faktor pengelolaan tanah/tindakan konservasi $(P)$ dalam penelitian ini yakni $P=1$, karena dapat dikatakan bahwa pada saat dilaksanakan penelitian tidak terdapat tindakan konsrvasi tanah dalam segala aspek penggunaan lahan di DAS Sedau. Tabel 4 menunjukkan nilai faktor CP untuk berbagai aspek pengelolaan lahan di DAS Sedau Kecamatan Singkwang Selatan yang mengacu pada Nilai Faktor Vegetasi Penutup Tanah dan Pengelolaan Tanaman (CP) yang terdapat dalam buku Hidrologi dan Pengelolaan Daerah Aliran Sungai (Asdak, 1995). 
Tabel 4.Nilai Faktor CP untuk berbagai aspek pengelolaan lahan di DAS Sedau pada tahun 2003 dan 2010

\begin{tabular}{ll|c|rlr}
\hline No & Tata Guna Lahan Tahun 2003 & CP & No & Tata Guna Lahan Tahun 2010 & CP \\
\hline 1 Hutan Primer & 0,001 & 1 & Bandara & 1 \\
2 & Hutan Sekunder & 0,005 & 2 & Hutan Konservasi & 0,001 \\
3 Kebun Campuran & 0,5 & 3 & Industri & 1 \\
4 & Sawah & 0,1 & 4 & Kawasan Wisata & 1 \\
5 Semak Belukar & 0,3 & 5 & Pelabuhan/Terminal & 1 \\
& & 6 & Perdagangan & 1 \\
& & 7 & Permukiman & 1 \\
& 8 & Pertambangan Terbatas & 1 \\
& & 9 & Pertanian Lahan Kering & 0,5 \\
& & 10 & Pertanian Tahunan & 0,1 \\
& & 11 & Peternakan dan Pertanian Terpadu & 0,1 \\
& 12 & RTH & 0,1 \\
& & 13 & RTH Kebun Botani & 0,1 \\
& & 14 & Tambak \\
\hline
\end{tabular}

Hasil pada tabel 4 menunjukkan terjadinya perubahan tata guna lahan pada tahun 2010 seperti menipisnya kawasan hutan dan meningkatnya kawasan pertanian lahan kering dan permukiman di DAS Sedau menyebabkan meningkatnya nilai faktor CP. Peningkatan factor CP pada penggunaan lahan ditahun 2010 juga dikarenakan tidak adanya tindakan konservasi tanah yang baik guna meminimalisir terjadinya potensi erosi. Terdapatnya konservasi tanah dengan tutupan lahan yang baik akan melindungi tanah dari butiran hujan secara langsung. Hal ini sesuai dengan pendapat Seta (1987) yang menyatakan bahwa setiap tanaman yang menutupi tanah adalah penghambat aliran permukaan. Dengan terhambatnya aliran permukaan, maka akan memberikan kesempatan pada air untuk masuk kedalam tanah (infiltrasi) sehingga jumlah aliran permukaan juga akan berkurang.

\section{F. Analisa Perhitungan Erosi}

Hasil perhitungan laju potensi erosi total dengan metode USLEpada DAS Sedau dari tahun 20032012 dapat kita lihat dalamgambardan tabel berikut ini.

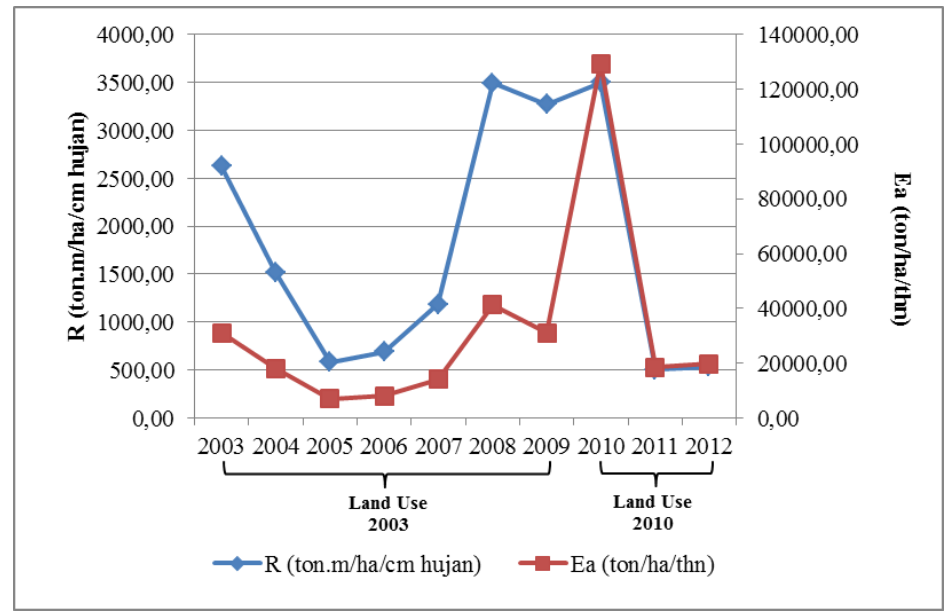

Gambar 2.Grafik pengaruh faktor erosivitas hujan (R) dan perubahan tata guna lahan terhadap hasil potensi erosi total di DAS Sedau

Gambar 2 menunjukkan pengaruh faktor erosivitas hujan (R) dan perubahan tata guna lahan terhadap hasil potensi erosi total di DAS Sedau.Data peta tata guna lahan tahun 2003 dihitung dengan fator erosivitas hujan dari tahun 2003-2009 dan data peta tata guna lahan tahun 2010 dihitung dengan 
factor erosivitas hujan dari tahun 2010-2102. Hasil pada grafik diatas menyimpulkan bahwa perubahan tata guna lahan yang terjadi pada tahun 2010 menyebabkan terjadinya potensi erosi yang besar di DAS Sedau jika terdapat faktor erosvitas hujan yang tinggi dalam waktu satu tahun. Gambaran lebih jelasnya tentang perubahan laju potensi erosi di DAS Sedau dapat dilihat pada gambar 3 berikut ini.

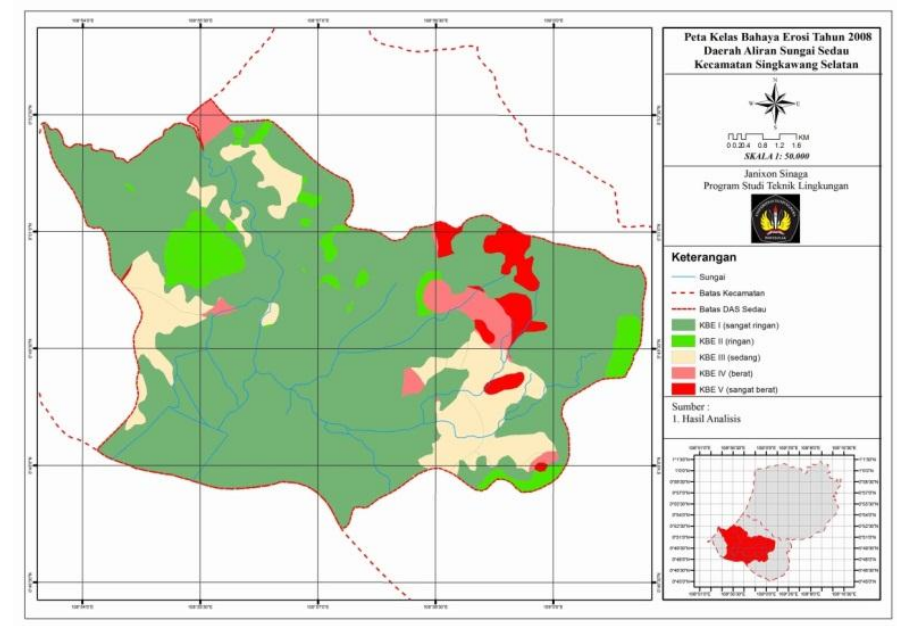

a. Tahun 2008

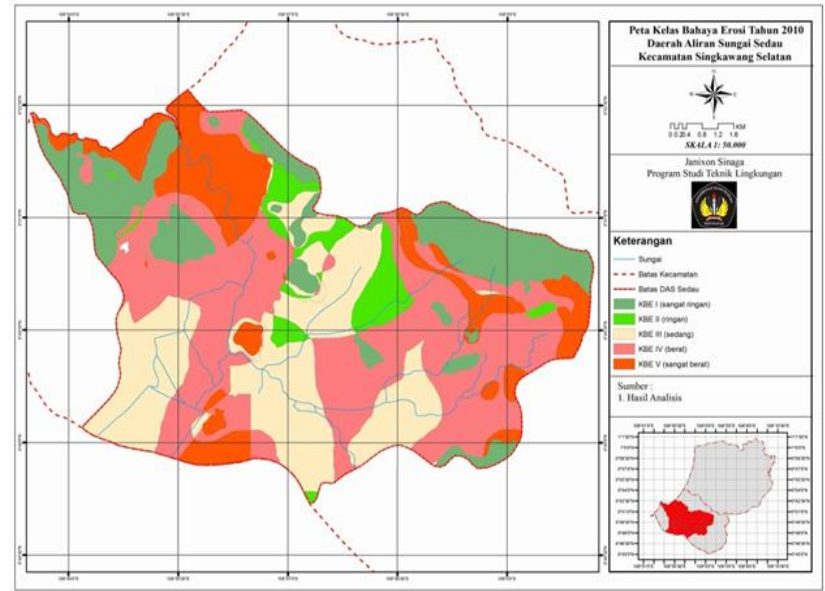

b. Tahun 2010

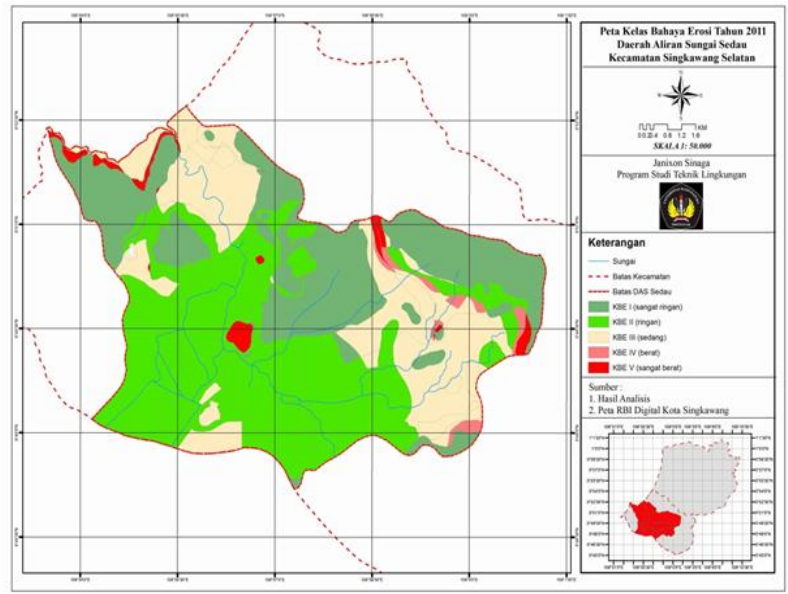

c. Tahun 2011

Gambar 3. Peta Kelas Bahaya Erosi di DAS Sedau

Gambar 3 menunjukkan perubahan kelas bahaya erosi di DAS Sedau pada tahun 2008, 2010 dan 2011. Hasil pada gambar 3a menunjukkan kondisi lahan kritis yang masuk dalam kelas bahaya erosi berat dan sangat berat di DAS Sedau hanya terdapat pada sebagian kecil lahan, hal ini dikarenakan penggunaan lahan pada tahun tersebut masih didominasi dengan kawasan hutan sehingga dapat meminimalisir tumbukan hujan secara langsung terhadap tanah yang dapat menyebabkan terjadinya erosi. Gambar 3b menunjukkan bahwa perubahan tata guna lahan yang terdapat pada tahun 2010, menyebabkan lahan potensial erosi yang besar mencakup lebih dari 50\% lahan di DAS Sedau, hal ini dikarenakan banyaknya penggunaan lahan yang kurang baik untuk meminimalisisr terjadinya potensi erosi seperti tingginya kawasan permukiman dan pertanian lahan kering serta erosivitas hujan yang tinggi pada tahun 2010 di DAS Sedau. Namun hasil pada gambar 4c menunjukkan bahwa besarnya luas lahan potensial erosi di DAS Sedau pada tahun 2010 tidak terjadi pada tahun 2011 dikarenakan erosivitas hujan yang terjadi pada tahun 2011 cukup rendah.

Berdasarkan hasil tersebut dapat dikatakan bahwa selain faktor pengunaan lahan, erosivitas hujan yang tinggi juga sangat mempengaruhi terjadinya potensi erosi yang besar, hal ini sesuai dengan yang dikemukakan oleh Sutedjo dan Kartasapoetra (2002) yakni air hujan yang menjadi air limpasan permukaan adalah unsur utama penyebab terjadinya erosi. Hujan dengan curahan dan intensitas yang tinggi, misalnya $50 \mathrm{~mm}$ dalam waktu singkat $(<1$ jam), lebih berpotensi menyebabkan erosi dibanding hujan dengan curahan yang sama namun dalam waktu yang lebih lama ( $>1 \mathrm{jam})$. 


\section{G. Analisa Kualitas Air}

Analisa kualitas air dilakukan untuk mengetahui pengaruh terjadinya erosi di DAS Sedau terhadap kondisi kualitas air di Sungai Sedau. Adapun pemeriksaan kualitas air hanya dilakukan pada dua parameter yakni kekeruhan dan TSS. Berikut ini merupakan hasil pengukuran kualitas air Sungai Sedau pada tahun 2013 berdasarkan baku mutu air kelas II PP RI Nomor 82 Tahun 2001 untuk parameter TSS dan baku mutu menurut Peraturan Menteri Kesehatan RI Nomor : 416/MENKES/PER/IX/1990 tentang persyaratan kualitas air bersih untuk parameter kekeruhan yang dapat dilihat pada tabel 5 berikut ini.

Tabel 5. Hasil Pengukuran Kualitas Air Sungai Sedau

\begin{tabular}{|c|c|c|c|c|c|c|c|}
\hline \multirow{2}{*}{ Parameter } & \multirow{2}{*}{$\begin{array}{c}\text { Alat / } \\
\text { Metode }\end{array}$} & \multirow{2}{*}{ Satuan } & \multirow{2}{*}{$\begin{array}{c}\text { Baku Mutu } \\
\text { Kelas II }\end{array}$} & \multicolumn{2}{|c|}{ Hasil Pemeriksaan } & \multicolumn{2}{|c|}{ Keterangan } \\
\hline & & & & $\mathrm{T1}$ & T2 & T1 & T2 \\
\hline 1 TSS & Gravimetrik & $\mathrm{mg} / \mathrm{l}$ & 50 & 21 & 18 & $\begin{array}{l}\text { Memenuhi standar } \\
\text { baku mutu }\end{array}$ & $\begin{array}{l}\text { Memenuhi standar } \\
\text { baku mutu }\end{array}$ \\
\hline 2 Kekeruhan & NTU & $\mathrm{mg} / \mathrm{l}$ & 25 & 26,6 & 25,1 & $\begin{array}{l}\text { Tidak memenuhi } \\
\text { standar baku mutu }\end{array}$ & $\begin{array}{l}\text { Tidak memenuhi } \\
\text { standar baku mutu }\end{array}$ \\
\hline
\end{tabular}

Analisa dari kualitas air Sungai Sedau untuk masing-masing parameter kualitas air adalah sebagai berikut :

\section{- TSS (Total Suspended Solid)}

Dari hasil pengukuran uji TSS di laboratorium pada kedua sampel air uji menunjukkan nilai kandungan TSS yang memenuhi standar baku mutu air kelas II menurut PP RI Nomor 82 Tahun 2001. Nilai TSS yang rendah ini dapat terjadi karena waktu pengambilan sampel air dilaksanakan saat kondisi cuaca cerah atau tidak terjadi hujan, sehingga bahan organik ataupun sel-sel mikroorganisme, dan sebagainya yang merupakan kandungan dari parameter TSS telah menjadi sedimen akibat adanya proses pengendapan.

\section{- Kekeruhan}

Dari hasil pengukuran uji kekeruhan di laboratorium, menunjukkan nilai kekeruhan pada kedua sampel air uji sedikit melebihi standar baku mutu menurut Peraturan Menteri Kesehatan RI Nomor : 416/MENKES/PER/IX/1990 tentang persyaratan kualitas air bersih untuk parameter kekeruhan. Nilai kekeruhan yang tidak begitu besar walaupun sedikit melebihi standar baku mutu pada kedua sampel air uji dapat terjadi karena waktu pengambilan sampel air dilaksanakan saat kondisi cuaca cerah atau tidak terjadi hujan dan pengambilan sampel air yang dilakukan pada $1 / 2$ dari total kedalaman sungai. Seperti yang diketahui bahwa adanya potensi erosi terjadi pada saat hujan turun karena adanya pelepasan partikel tanah yang disebabkan oleh air hujan. Kondisi cuaca yang cerah pada saat pengambilan sampel air telah menyebabkan terjadinya proses pengendapan pada partikel-partikel tanah yang terdapat pada air sungai sehingga partikel-partikel tanah tersebut telah menjadi sedimen didasar sungai. Selain itu diketahui pula bahwa pemeriksaan nilai kandungan TSS pada sampel air yang sama cukup rendah, hal ini sebanding dengan nilai kekeruhan yang tidak begitu besar dikarenakan kekeruhan merupakan banyaknya zat tersuspensi pada suatu perairan.

\section{H. Upaya Konservasi Lahan Potensial Erosi}

Tujuan upaya konservasi lahan potensial erosi selain untuk meminimalkan potensi erosi secara umum juga untuk meningkatkan produktivitas lahan secara maksimal, memperbaiki lahan yang rusak/kritis, dan melakukan upaya pencegahan kerusakan tanah akibat erosi. Dari hasil identifikasi hasil pada potensi erosi yang terjadi, diketahui bahwa lahan potensial erosi terbesar berdasarkan penggunaan lahan di DAS Sedau ialah pertanian lahan kering, permukiman dan kawasan wisata. Berikut ini dijelaskan contoh upaya konservasi lahan yang dapat diterapkan pada daerah pertanian lahan kering, permukiman dan kawasan wisata di DAS Sedau :

\section{a. Metode Vegetatif}

Teknik konservasi tanah secara vegetatif yang dapat diterapkan pada pertanian lahan kering di DAS Sedau yakni dengan memberikan tanaman penutup tanah yang rapat atau dengan pemberian mulsa (sisa tanaman, serasah, sampah, plastik atau bahan-bahan lain) yang disebar untuk menutup permukaan tanah guna melindungi permukaan tanah dari pukulan langsung butiran hujan sehingga mengurangi terjadinya erosi percik (splash erosion) dan mengurangi laju dan volume limpasan 
permukaan (Suwardjo, 1981). Teknik konservasi tanah secara vegetatif kerap digunakan pada lahan pertanian dengan kondisi lereng yang datar, selain itu dengan adanya tindakan konservasi tanah secara vegetatif maka akan meminimalisir nilai factor CP pada pertanian lahan kering di DAS Sedau yang sebelumnya 0,5 (disertai penutup tanah sedang) menjadi 0,1 (disertai penutup tanah rapat) (Asdak, 1995). Selain itu konservasi tanah secara vegetatif juga dapat diterapkan pada daerah permukiman dan kawasan wisata yakni dengan meningkatkan pertumbuhan tanaman seperti pepohonan dan rerumputan dilahan yang masih bisa ditanami ataupun dengan pembuatan taman di kawasan wisata. Dengan meningkatnya pertumbuhan tanaman secara tidak langsung akan meningkatkan kapasitas infiltrasi pada tanah dan juga mengurangi tumbukan hujan secara langsung ke tanah.

\section{b. Metode Mekanik}

Teknk mekanik yang dapat diterapkan untuk pertanian lahan kering di DAS Sedau misalnya dengan pembuatan teras gulud dan teras bangku.Teras gulud umumnya dibuat pada lahan dengan kemiringan $10-15 \%$ yang biasanya dilengkapi dengan saluran pembuangan air yang tujuannya untuk mengurangi kecepatan air yang mengalir pada waktu hujan sehingga erosi dapat dicegah dan penyerapan air dapat diperbesar. Teras bangku sering diterapkan pada lereng $10-40 \%$ yang merupakan teras yang dibuat dengan cara memotong lereng dan meratakannya dengan dibidang olah sehingga terjadi deretan menyerupai tangga yang bermanfaat sebagai pengendali aliran permukaan dan erosi. Adanya penerapan tindakan konservasi tanah secara mekanik pada pertanian lahan kering di DAS Sedau dengan begitu akan meminimalisir nilai factor CP yang sebelumnya 0,5 menjadi 0,06 (untuk teras bangku) dan 0,01 (untuk teras gulud) (Asdak, 1995)..Pada daerah permukiman dan kawasan wisata,teknik mekanik untuk konservasi tanah yang dapat diterapkan yakni dengan pembuatan lubang resapan biopori.Lubang resapan biopori berfungsi untuk meningkatkan daya resapan air kedalam tanah sehingga dapat meminimalisir terjadinya potensi erosi jika hujan turun.

\section{Kesimpulan dan Saran}

\section{A. Kesimpulan}

Berdasarkan hasil penelitian yang telah dilakukan, kesimpulan yang dapat diambil ialah :

a. Perubahan tata guna lahan yang terjadi di DAS Sedau Kecamatan Singkawang Selatan menghasilkan potensi erosi yang besar jika terjadi faktor erosivitas hujan yang tinggi dalam satu tahun. Hasil analisa perhitungan menunjukkan, laju potensi erosi di DAS Sedau dalam jumlah yang besar terjadi pada tahun 2010 dengan nilai erosivitas hujan sebesar 3489,94 ton.m/ha/cm hujan, mengakibatkan luas lahan yang masuk dalam kriteria kelas bahaya erosi berat dan sangat berat sebesar 4303,09 ha. Laju potensi erosi di DAS Sedau dalam jumlah yang kecil terjadi pada tahun 2011 dengan nilai erosivitas hujan hanya sebesar 535,71 ton.m/ha/cm hujan mengakibatkan luas lahan yang masuk dalam kriteria kelas bahaya erosi berat dan sangat berat hanya sebesar 271,95 ha.

b. Terjadinya erosi di DAS Sedau juga cukup mempengaruhi kualitas air di Sungai tersebut, hasil pemeriksaan parameter kekeruhan pada sampel air uji yang diambil dari 2 titik lokasi yakni T1=26,6 $\mathrm{mg} / \mathrm{l}$ dan $\mathrm{T} 2=25,1 \mathrm{mg} / \mathrm{l}$, hasil tersebut menunjukkan bahwa kondisi kekeruhan air di Sungai Sedau melebihi baku mutu air bersih menurut Peraturan Menteri Kesehatan RI Nomor : 416/MENKES/PER/IX/1990 tentang persyaratan kualitas air bersih untuk parameter kekeruhan yakni sebesar $25 \mathrm{mg} / \mathrm{l}$.

c. Adapun rekomendasi upaya konservasi lahan yang dapat dilakukan antara lain :

a. Konservasi vegetatif : meningkatkan pertumbuhan tanaman disekitar lahan pertanian/perkebunan, permukiman serta kawasan wisata yang berfungsi untuk melindungi permukaan tanah dari pukulan langsung butiran hujan sehingga mengurangi terjadinya erosi percik (splash erosion) dan mengurangi laju dan volume limpasan permukaan. 
b. Konservasi mekanik : pembuatan teras gulud dan teras bangku pada pertanian lahan kering sesuai dengan kemiringan lahan/garis kontur dan bisa juga dilengkapi dengan pembuatan saluran air yang tujuannya untuk mengurangi kecepatan aliran air pada waktu hujan, sehingga erosi dapat dicegah dan penyerapan air dapat diperbesar. Untuk daerah permukiman dan kawasan wisata tindakan konservasi yang dapat dilakukan berupa pembuatan lubang resapan biopori yang dapat meningkatkan daya resapan air kedalam tanah sehingga dapat meminimalisir terjadinya potensi erosi jika hujan turun.

\section{B. Saran}

Saran yang coba dituangkan dari hasil studi penelitian "Analisis Potensi Erosi pada Penggunaan Lahan Daerah Aliran Sungai Sedau di Kecamatan Singkawang Selatan", yakni dalam terwujudnya upaya tindakan pengendalian erosi diperlukan dukungan dari berbagai pihak baik individu, masyarakat, swasta dan pemerintah yang harus bersama-sama melakukan upaya tersebut, sehingga dampak negatif yang dapat timbul akibat erosi seperti sedimentasi dan banjir dapat diminimalkan.

\section{Ucapan Terima Kasih}

Dalam penulisan jurnal ini penulis mengucapkan terima kasih kepada kedua orang tua yang selalu mendoakan dan mendukung penulis. Terima kasih kepada Ibu Dr. Ir. Hj. Kartini, MT dan Ibu Erni Yuniarti, ST., MT selaku dosen pembimbing serta Bapak Ir. H. Nasrullah, MT dan Ibu Rizki Purnaini, ST., MT selaku dosen penguji. Tidak lupa pula kepada teman-teman angkatan 2008 Fakultas Teknik UNTAN yang telah banyak memberikan motivasi dan dukungan kepada penulis.

\section{Referensi}

Arsyad, S. 1989. Konservasi Tanah dan Air. IPB, Bogor.

Asdak, Chay. 1995. Hidrologi dan Pengelolaan Daerah Aliran Sungai. Gadjah Mada University Press. Yogyakarta.

Badan Perencanaan dan Pembangunan Daerah Kota Singkawang Provinsi Kalimantan Barat. 2012. Profil Daerah Kota Singkawang. Singkawang.

Kartasapoetra., A., 2002. Klimatologi Pengaruh Iklim terhadap Tanah dan Tanaman. Bumi Aksara, Jakarta.

Kironoto, B.A., 2003, Diktat Kuliah Hidraulika Transpor Sedimen. PPS-Teknik Sipil. Yogyakarta.

Nasution, MI. 2008. Penentuan Jumlah Amoniak dan Total Padatan Tersuspensi Pada Pengolahan Air Limbah PT. Bridgestone Sumatera Rubber Estate Dolok Merangkir. Universitas Sumatera Utara. Medan.

PERMENKES RI (Peraturan Menteri Kesehatan Republik Indonesia) Nomor 416/MENKES/PER/IX/1990 tentang Persyaratan Kualitas Air Bersih.

PP RI (Peraturan Pemerintah Republik Indonesia) Nomor 82 Tahun 2001 tentang Pengelolaan Kualitas Air dan Pengendalian Pencemaran Air.

Seta, A. K., 1987.Konservasi Sumber Daya dan Air. Kalam Mulia, Jakarta.

Suripin., 2004. Pengembangan Sistem Drainase yang Berkelanjutan. Andi Offset, Yogyakarta.

Sutapa, I., 2010. Analisis Potensi Erosi pada Daerah Aliran Sungai (DAS) di Sulawesi Tengah. Jurnal Smartek, Vol. 8. No. 3. Palu.

Sutedjo, M. M. dan A. G. Kartasapoetra. 2002. Pengantar Ilmu Tanah. Cetakan Ketiga. Rineka Cipta. Jakarta

Suwardjo. 1981. Peranan Sisa-Sisa Tanaman dalam Konservasi Tanah dan Air pada Usahatani Tanaman Semusim. Disertasi FPS IPB. Bogor. 